\title{
ADULT EDUCATION: REACHING THE UNREACHED
}

EUGENIA A. PANITSIDES, HELLENIC OPEN UNIVERSITY, GREECE 
Executive Summary

The adoption of the Sustainable Development Goals in 2015 was welcome globally, mainstreaming sustainability in all sectors, including education and training under Goal 4, which advocated "inclusive and equitable quality education and promotion of lifelong learning opportunities for all". However, is it realistic to attain a substantially equitable adult education policy amidst the hegemony of neoliberal regimes and utilitarian approaches? Our data, drawn from the OECD Survey of Adult Skills and the European Adult Education Survey (AES), highlight, in alignment with relevant research, that education and training opportunities are still significantly unequal, failing to reach those adults more at risk, reproducing a "Matthew" effect. Against this backdrop, the present policy brief reiterates important parameters that have emanated from relevant research, which can formulate a set of concrete measures that bear the potential to facilitate the "unreached" not simply to participate, but also to substantially benefit from adult education, mitigating social inequalities. 


\section{Introduction}

The invisible thread between Adult Education (AE) and social justice, has long been at the forefront of the political agenda, with the two seminal policy papers under the auspices of UNESCO (Delors, 1996; Faure et al., 1972) fueling the debates on the paramount role of AE in alleviating poverty and combating exclusion. In an increasingly unsettled, complex, and rapidly-changing world, amidst the combined effects of recent demographic trends such as ageing societies and refugee crises, and of the escalating environmental and economic challenges, inclusive and sustainable growth is a sine-qua-non for safeguarding an equitable and decent standard of life for all citizens (European Commission, 2019, 2020).

\section{Findings}

The United Nations (UN) introduced the Sustainable Development Goals (SDGs) to the global community in 2015 within the context of the 2030 Agenda for Sustainable Development, stressing that no one can be left behind. The adoption of the SDGs was welcomed globally, including the European Union (EU) (Official Journal of the European Union, 2020), as an integral agenda which mainstreams sustainability in all sectors. Among the 17 goals with 169 subindicators, goal 4 is related to education and learning, catering for "inclusive and equitable quality education and promotion of lifelong learning opportunities for all" (UN, 2015, p.14). Yet, how realistic is the attainment of a truly equitable AE policy amidst the hegemony of neoliberal regimes and utilitarian approaches?

AE was brought to the forefront of EU policies due to the confrontation with escalating unemployment rates in the 1990s, endorsing two White Papers which outlined the crucial impact of AE in growth and social justice (European Commission, 1993, 1995). At the turn of the millennium, AE, under the lifelong learning conceptualization, was determined to lead an even more prominent role. After two decades and the endorsement of two ambitious strategic frameworks - the "Lisbon Strategy" and "Europe 2020" - informed by human capital mandates, reorienting EU policies to capture the benefits of the knowledge-based economy, and propounding AE as a panacea in fostering prosperity and combating social exclusion (Panitsides, 2015; Panitsides \& Anastasiadou, 2015), where do we stand today?

Unfortunately, high aspirations have not been met by substantially encouraging results (European Commission, 2019). AE is identified in relevant studies (Bağcı, 2019; Boeren, 2009; Kosyakova \& Bills, 2021; Tuparevska, Santibáñez, \& Solabarrieta, 2020) as the mechanism that has reproduced a Matthew effect ${ }^{1}$, privileging those with an already sound educational background.

UNESCO (2019) and OECD (2021) reiterate the lack of equality in education and training opportunities, failing to reach the most vulnerable. On average, across OECD countries, participation in AE by those with lower education is one-third of that of highly educated adults, whilst workers whose jobs are at high risk of automation are one half less likely to engage in AE than their peers in lower-risk jobs (OECD, 2021: 7). And these figures have not yet reflected the aggregate impact of the COVID-19 crisis and the recession it has thrown the world into, escalating inequalities, which, if not effectively addressed, may result in deeper social divisions (European Commission, 2020). In Table 1, we have drawn data from the OECD Programme for the International Assessment of Adult Competencies (PIAAC) and the Survey of Adult Skills (OECD, 2019).

Table 1. Skills Matter: Results from the survey of Adult Skills

\begin{tabular}{|c|c|c|c|c|c|c|c|c|}
\hline & \multicolumn{2}{|c|}{$\begin{array}{l}\text { Lower than upper } \\
\text { secondary }\end{array}$} & \multicolumn{2}{|c|}{ Upper secondary } & \multicolumn{2}{|c|}{ Tertiary } & \multicolumn{2}{|c|}{$\begin{array}{l}\text { Difference between } \\
\text { adults with tertiary and } \\
\text { adults with lower than } \\
\text { upper secondary }\end{array}$} \\
\hline & $\begin{array}{l}\text { Mean } \\
\text { score }\end{array}$ & S.E.* & $\begin{array}{l}\text { Mean } \\
\text { score }\end{array}$ & S.E. & $\begin{array}{l}\text { Mean } \\
\text { score }\end{array}$ & S.E. & Dif. & S.E. \\
\hline $\begin{array}{l}\text { Mean literacy proficiency, by educational } \\
\text { attainment, and score difference between high- and } \\
\text { low-educated adults OECD average }\end{array}$ & 230,3 & $(0,4)$ & 263,0 & $(0,2)$ & 290,8 & $(0,3)$ & 60,5 & $(0,0)$ \\
\hline $\begin{array}{l}\text { Mean numeracy proficiency, by educational } \\
\text { attainment, and score difference between high- and } \\
\text { low-educated adults } \\
\text { OECD average }\end{array}$ & 220,9 & $(0,4)$ & 259,9 & $(0,3)$ & 291,2 & $(0,3)$ & 70,3 & $(0,0)$ \\
\hline $\begin{array}{l}\text { Mean literacy proficiency and score difference, by } \\
\text { parents' educational attainment OECD average }\end{array}$ & 248,9 & $(0,3)$ & 273,0 & $(0,3)$ & 289,4 & $(0,3)$ & 40,5 & $(0,4)$ \\
\hline $\begin{array}{l}\text { Mean numeracy proficiency and score difference, by } \\
\text { parents' educational attainment } \\
\text { OECD average }\end{array}$ & 243,6 & $(0,3)$ & 268,9 & $(0,3)$ & 287,2 & $(0,4)$ & 43,7 & $(0,5)$ \\
\hline
\end{tabular}


As it is clearly depicted by the mean scores recorded in numeracy and literacy proficiency, both participants' and their parents' educational background is directly related to their literacy and numeracy skills. In other words, the context somebody is born and brought up in is predictive of his/her future educational attainment and consequently social status. The 'inheritors' of economic, social and cultural capitals and the reproductive deadlock these capitals exert over individuals have long reigned sociological debates (Bourdier, 1986; Bourdieu \& Passeron, 1979). Yet, with the rhetoric of political discourses repetitively drawing on the potential of $A E$ in combating social exclusion and the respective policies enforced to increase both investment and participation in $A E$, the existing chasmic inequalities should set alarm bells ringing to policy makers: 'Disadvantaged" individuals have been steadily under-represented in AE activities. In Table 2, data were drawn from the European Adult Education Survey (AES) (Eurostat, n.d.) portraying AE participation based on a 12-month period. Educational attainment, labour status and occupation were selected as weighty factors in explaining inequalities in participation.

Table 2. Adult Education Survey

\begin{tabular}{|c|c|c|c|c|c|c|c|c|c|c|c|c|}
\hline \multicolumn{10}{|c|}{ Participation rate in education and training by educational attainment level } & & & \\
\hline & \multicolumn{3}{|c|}{$\begin{array}{l}\text { Less than primary, primary and } \\
\text { lower secondary education (levels } \\
0-2 \text { ) }\end{array}$} & \multicolumn{3}{|c|}{$\begin{array}{l}\text { Upper secondary and post- } \\
\text { secondary non-tertiary education } \\
\text { (levels } 3 \text { and } 4 \text { ) }\end{array}$} & \multicolumn{3}{|c|}{ Tertiary education (levels $5-8$ ) } & & & \\
\hline & 2007 & 2011 & 2016 & 2007 & 2011 & 2016 & 2007 & 2011 & 2016 & & & \\
\hline EU 27 & 14.9 & 22.2 & 22.9 & 31.4 & 37.7 & 40.3 & 56.8 & 63.2 & 64.5 & & & \\
\hline \multicolumn{7}{|c|}{ Participation rate in education and training by labour status } & & & & & & \\
\hline & \multicolumn{3}{|c|}{ Employed persons } & \multicolumn{3}{|c|}{ Unemployed persons } & & & & & & \\
\hline & 2007 & 2011 & 2016 & 2007 & 2011 & 2016 & & & & & & \\
\hline EU 27 & 40.0 & 48.8 & 51.8 & 23.1 & 26.1 & 27.8 & & & & & & \\
\hline \multicolumn{7}{|c|}{ Participation rate in education and training by occupation } & & & & & & \\
\hline & \multicolumn{3}{|c|}{$\begin{array}{l}\text { Managers, professionals, } \\
\text { technicians and associate } \\
\text { professionals }\end{array}$} & \multicolumn{3}{|c|}{$\begin{array}{l}\text { Clerical support workers, service } \\
\text { and sales workers }\end{array}$} & \multicolumn{3}{|c|}{ Skilled manual workers } & \multicolumn{3}{|c|}{ Elementary occupations } \\
\hline & 2007 & 2011 & 2016 & 2007 & 2011 & 2016 & 2007 & 2011 & 2016 & 2007 & 2011 & 2016 \\
\hline EU 27 & 56.6 & 65.4 & 67.3 & 41.6 & 45,3 & 47.2 & 28.0 & 32.7 & 35.6 & 21.0 & 27.8 & 30.9 \\
\hline \multicolumn{10}{|c|}{ Mean Instruction hours spent by participant in education and training by educational attainment level } & & & \\
\hline & \multicolumn{3}{|c|}{$\begin{array}{l}\text { Less than primary, primary and } \\
\text { lower secondary education (levels } \\
0-2 \text { ) }\end{array}$} & \multicolumn{3}{|c|}{$\begin{array}{l}\text { Upper secondary and post- } \\
\text { secondary non-tertiary education } \\
\text { (levels } 3 \text { and } 4 \text { ) }\end{array}$} & \multicolumn{3}{|c|}{ Tertiary education (levels $5-8$ ) } & & & \\
\hline & 2007 & 2011 & 2016 & 2007 & 2011 & 2016 & 2007 & 2011 & 2016 & & & \\
\hline EU 27 & 114 & 103 & 98 & 128 & 125 & 110 & 143 & 139 & 131 & & & \\
\hline
\end{tabular}

AES was carried out in 2007, 2011 and 2016, and although there is recorded an increase in participation figures, the striking differences between highly educated individuals, employed, and in white collar jobs, and those mostly in need - that is, with lower educational background, unemployed, and in elementary occupations - cannot be ignored. They apparently denote that adult education policies enforced so far have failed to disrupt the negative reinforcement between disadvantage and social exclusion.

\section{Implications}

The above data clearly illustrate the failure to draft the right mixture of policies, grounded on "equity" approaches (OECD, 2012), aimed to enhance the social effectiveness of AE and tackle inequality and social exclusion. They apparently imply that a greater variety of measures are demanded to meet the multiple and complex needs of the deprived ones (Tuparevska, Santibáñez, \& Solabarrieta, 2020). To this end, all parties involved - researchers, policymakers, and providers - should be mobilized towards understanding the necessity of targeted action and systematic application of positive discrimination measures to enable the most vulnerable not simply to participate, but also to substantially benefit from AE. Unless AE policy effectively reaches out to the most vulnerable, it can be no more than a vehicle that reproduces a Matthew effect; simply, the privileged ones take it all!

\section{Recommendations: A model of want not need}

Our research on the participation of disadvantaged social groups in AE (Panitsides, 2013, 2017; Panitsides \& Kiouka, 2018; Panitsides, Loti Papastamatis \& Valcanos, 2016; Papastamatis \& Panitsides 2009) has indicated that it takes comprehensive approaches demanding effort, time, resources, and expert knowledge to overcome the various situational, dispositional and institutional barriers (Cross, 1981), with the dispositional ones identified to exert principal influence on the "non-learners" (UNESCO, 2019). If the aim is to substantially raise participation in AE among individuals least prepared or inclined, or with little opportunity to learn, policies should ensure ample financial resources and draw on concrete measures that may help AE reach out to the unreached, such as: 
- Overcoming the confinement of AE in attaining the targets set by the growth strategies enforced. Constrained by mandates to increase participation indexes both governments and providers are eager to quantitively increase participation, restricting the social effectiveness of AE: the "learners" prevail as they are markedly more prone to participate.

- Opting for flexibility and setting limits on the technocratic modus operandi. Most often provision, especially in EU-funded programmes, is bound to increase accountability within a quality assurance framework, following centrally set specifications as regards the duration, methods, and contents, which accounts for the failure to respond to diverse regional, local, and individual needs and demands. After all, the quality of AE programmes primarily relies on ensuring adequate financing for state-of-the-art infrastructure, cutting edge educational materials and retention of competent educators.

- Realizing that dispositional barriers have a major impact both on participation and dropout rates of disadvantaged individuals in AE. Educators and Counselors can play a major role to uplift such barriers by building an atmosphere of mutual trust, openness, honesty, and acceptance.

- Channeling adequate resources into the training of adult educators. As mentioned above, possible dispositional barriers concerning educational institutions could be overcome through the enthusiasm and teaching competence of the educator, by establishing an open, friendly, and relaxed atmosphere during courses so that learners can feel confident to express themselves, take active participation in the learning process and build on their self-confidence.

- Acknowledging the role of 'key-persons'. In certain vulnerable communities, such as Minorities, Romas, and Refugees, it is important to approach key persons as first attendees in a targeted way, as well as to promote public relations with local authorities and community representatives. Individuals belonging to such groups are initially overly reserved, lacking trust to $A E$, as both providers and educators are often carriers of a different culture and religion.

- Decentralizing and bringing learning closer to home. This is attained by operating AE programmes at decentralized locations to reduce the distance and enhance the sense of familiarity, especially in culturally and economically deprived communities ${ }^{2}$. If AE policies are to cater for "equity', then the allocation of funds should not be realized on a cost/profit basis, investing mostly in urban areas where the return rates are expected to be higher.

- Involving local authorities in the design, provision, and financing of AE. Decentralization of AE can reinforce the optimal tailoring of the supply to local needs and demands, as well as the adjustment of strategies in reaching the "unreached", facilitating the delivery of programmes of diverse types for diverse individuals and communities, traditionally discouraged by or excluded from educational activities.

- Eliminating costs is vital to enhance accessibility. Eliminating cost, along with open entry requirements, are major parameters in enabling access to courses for vulnerable social groups.

In effect, against the backdrop of the current environmental challenges and the Covid-19 economic impact, deepening recession, imposing marginalization of larger groups, and accentuating social inequalities, "leaving no one behind" is the ultimate mandate. On these grounds, the above recommendations bear significant potential to widen participation in AE and cater for skill deficiencies among individuals more susceptible to the crisis impact, prohibiting their exclusion from the economic and social spheres.

\section{Contact details}

Dr Eugenia A. Panitsides, Hellenic Open University, and HETL Country Director (Greece), panitsidou.evgenia@ac.eap.gr 


\section{References}

Bağcı \$̧.E. (2019). Migration and Participation in Adult Education: The Matthew Effect on Immigrants. Adult Education Quarterly, 69(4), 271-294. doi. org/10.1177/0741713619848108

Boeren, E. (2009). Adult education participation: the Matthew principle. Filosofija- Sociologija, 20(2), 154-161. Bourdieu, P. (1986). The forms of capital. In J. Richardson (ed.) Handbook of Theory and Research for the Sociology of Education (pp. 241-258). New York: Greenwood

Bourdieu, P. \& Passeron, J.C. (1979). The Inheritors: French Students and Their Relations to Culture. Chicago: University of Chicago Press.

Cross, P. (1981). Adults as Learners. San Francisco: Jossey-Bass.

Delors, J. (1996). Learning: The Treasure Within. Report to UNESCO of the International Commission on Education for the Twenty-First Century. Paris: UNESCO. https://unesdoc.unesco.org/ark:/48223/pf0000109590 European Commission (1993). White Paper on Growth, Competitiveness, Employment: The Challenges and Ways Forward into the 21st Century. Brussels: COM700. https://op.europa.eu/en/publication-detail/-/publication/0d563bc1-f17e-48ab-bb2a-9dd9a31d5004

European Commission (1995). White Paper on Education and Training: Teaching and learning, towards the learning society. Brussels: COM590. https://op.europa. eu/en/publication-detail/-/publication/d0a8aa7a-53114eee-904c-98fa541108d8/language-en

European Commission (2019). Assessment of the Europe 2020 Strategy. Joint report of the Employment Committee and Social Protection Committee. Luxembourg: Publications Office of the European Union.

https://ec.europa.eu/social/main.jsp?-

catld =738\&langld =en\&publd =8256\&furtherPubs=yes

European Commission (2020). Annual Sustainable Growth Strategy 2021. Brussels: COM(2020)575. https:// eur-lex.europa.eu/legal-content/en/ALL/? uri=CELEX52020DC0575

European Council (2019). A New Strategic Agenda 2019 - 2024. Brussels: EC. https://www.consilium.europa.eu/ media/39914/a-new-strategic-agenda-2019-2024.pdf Eurostat (n.d.). Adult Education Survey. Retrieved from https://ec.europa.eu/eurostat/web/education-and-training/data/database

Faure, E., Herrera, F., Kaddoura, A., Lopes, H., Petrovski, A.V., Rahnema, M., \& Ward, F.C. (1972). Learning to Be: The world of education today and tomorrow. Paris: UNESCO. https://unesdoc.unesco.org/ark:/48223/ pf0000001801

Kosyakova, Y. \& Bills, D.B. (2021). Formal adult education and socioeconomic inequality: Second chances or Matthew Effects? Sociology Compass, 1-15, DOI: 10.1111/soc4.12920 https://onlinelibrary.wiley.com/doi/ full/10.1111/soc4.12920

OECD (2012). Equity and Quality in Education: Supporting Disadvantaged Students and Schools. Paris: OECD Publishing. http://dx.doi.org/10.1787/9789264130852-en OECD (2019). Skills Matter: Additional Results from the Survey of Adult Skills. Paris: OECD Publishing. https:// www.oecd-ilibrary.org/education/skills-matter_1f029d8f-en
OECD (2021). OECD Employment Outlook 2021: Navigating the COVID-19 Crisis and Recovery. Paris: OECD Publishing. https://doi.org/10.1787/5a700c4b-en.

Official Journal of the European Union (2020). Opinion of the European Economic and Social Committee on Leaving no one behind when implementing the 2030 Sustainable Development Agenda. Brussels: 2020/C 47/05. https://www.eesc.europa.eu/en/our-work/opinions-information-reports/opinions/leaving-no-one-behind-when-implementing-2030-sustainable-development-agenda-own-initiative-opinion

Panitsides E.A. (2013). Researching returns emanating from participation in adult education courses: a quantitative approach. International Journal of Lifelong Education, (32)5, 600-619. DOl:10.1080/02601370.2012.7531 23.

Panitsides E.A. (2015). Towards 'utilitarian' adult education perspectives? A critical review of the European Union adult education policy. In M. Milana \& T. Nesbit (eds) Adult Education and Learning Policy: A Worldwide Review (pp. 207-220). NY, USA: Palgrave Macmillan. Panitsides E.A. \& Anastasiadou S. (2015). Lifelong Learning Policy Agenda in the European Union: A bi-level analysis. Open Review of Educational Research, (2)1, 128-142. DOI: 10.1080/23265507.2015.1043936. https:// www.tandfonline.com/doi/full/10.1080/23265507.2015. 1043936

Panitsides E.A., Loti S., Papastamatis A, \& Valcanos, E. (2016). Lifelong Learning in the European Union. Training the unemployed: Panacea or Sisyphus syndrome? In E.A. Panitsides \& J. Talbot (eds) Lifelong Learning: Concepts, Benefits and Challenges (pp. 79-94). NY, USA: Nova Science.

Panitsides E.A. (2017). Policies for Lifelong Learning: A "portal" to social inclusion? In G. Verma \& D. Kalenkin-Fishman (eds) Educational and Social Inclusion (pp. 105-118). London: Routledge.

Panitsides, E.A. \& Kiouka, I.A. (2018). Muslim Minority women in Western Thrace: Any room for transformative learning?. Education and Training, 60(6), 596-607. https://www.emerald.com/insight/content/doi/10.1108/ ET-02-2018-0052/full/html? skipTracking=true

Papastamatis A, Panitsides E.A. (2009). The Aspect of 'accessibility' in the Light of European Lifelong Learning Strategies. Adult Education Centres: A case study. International Journal of Lifelong Education, (28)4, 335-351. doi.org/10.1080/02601370902799143

Tuparevska, E., Santibáñez, R., \& Solabarrieta, J. (2020). Equity and social exclusion measures in EU lifelong learning policies. International Journal of Lifelong Education, 39(1), 5-17. doi.org/10.1080/02601370.2019.1689 435 https://www.tandfonline.com/doi/epub/10.1080/02 601370.2019.1689435? needAccess =true

UNESCO (2019). 4th Global Report on Adult Learning and Education. Leave no one behind: participation, equity and inclusion Hamburg: UNESCO Institute for Lifelong Learning. https://unesdoc.unesco.org/ark:/48223/ pf0000372274

United Nations (UN) (2015). Transforming our world: the 2030 Agenda for Sustainable Development. UN: A/ RES/70/1. https://www.un.org/ga/search/view_doc. asp?symbol=A/RES/70/18Lang =E 